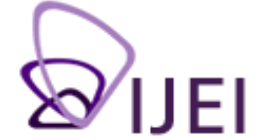

International

Journal for

Educational

Integrity

\title{
International postgraduate students' experiences of plagiarism education in the UK: Student, tutor and expert perspectives
}

\author{
Mary Davis \\ Oxford Brookes University, UK \\ marydavis@brookes.ac.uk
}

A version of this paper was previously included in the International Integrity and Plagiarism Conference Proceedings, Newcastle-upon-Tyne, UK, 16-18 July 2012.

Keywords: plagiarism education, plagiarism definition, international postgraduate, source use, academic literacy

\begin{abstract}
The role of plagiarism education is being increasingly highlighted as a key area of learning good academic practice, but to date, few case studies have focused on international ${ }^{1}$ postgraduate students' experiences of plagiarism education. Therefore, this study examines the experiences of eight Asian and North African international students at the end of Master's degrees at a UK university. In addition, interviews with their postgraduate tutors were made in order to gather further insights. The students and tutors reported different understandings of the university's plagiarism definition and problems with the availability of plagiarism education. Students reported that support was limited and they had many concerns about plagiarism; tutors reported that they lacked time or thought instruction should be provided elsewhere. At the same time, the tutors recognised that they required students to use sources at a high level. Interviews were also made with a number of global plagiarism education experts, who called for a greater focus on learning rather than just following regulations, less outsourcing of the problem, and more awareness about the tendency to connect international students with plagiarism. The study emphasises the need for more attention to plagiarism definitions and to international students' experiences of plagiarism education through continuous pedagogical support during their study.
\end{abstract}

\section{Introduction}

It has been well established in recent research that learning to use sources appropriately is a difficult, confusing and long process (Chanock, 2008; Davis \& Carroll, 2009; McCulloch, 2012). This is especially, though by no means exclusively, true for international postgraduate students who have learnt different academic conventions in undergraduate degrees in other settings (Braine, 2002) and have to adapt to new ones very quickly (McGowan, 2005). Despite the attention drawn to problems with plagiarism, it seems there is still not enough pedagogical support with source use (Murray \& Kirton, 2006). In a UK study, Bennett (2005) also confirmed that tutors tend to think that international students plagiarise more and are more likely to be caught; this is especially the case when tutors notice a change in discourse style from the students' current level demonstrated elsewhere to one more expert or highly academic (Bull et al., 2001).

In this context of problems related to plagiarism and international students, a growing body of research is emerging which calls for a prioritisation of plagiarism education. Carroll (2007) has promoted the holistic approach, involving all stakeholders in the

The International Journal for Educational Integrity is available online at:

http://www.ojs.unisa.edu.au/journals/index.php/lJEl/

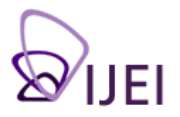


learning process, deterring plagiarism through better task design and using many means to teach good practice through varied input, practice and engagement. Plagiarism education also involves a discussion of the grey areas of plagiarism (Sutherland-Smith, 2008), and what Howard (2008) calls the 'pluralising' of plagiarism through debate and engagement, rather than exclusively through the application of university regulations. Pecorari (2008) adds to this argument by highlighting the complexity of plagiarism, and the many factors affecting it, including linguistic level, educational background, understanding of conventions and confidence with academic literacy.

Studies of how universities define plagiarism have shown some important differences and possible problems for students. In a survey by Pecorari (2001) of 54 universities in the US, UK and Australia, the main differences found in the definitions were related to the amount of detail, whether plagiarism was considered intentional or not, and how readily available the information appeared to be. In a similar study by SutherlandSmith (2008) of university policies in Australia, Canada, the US, England, New Zealand and China, definitions ranged from graded levels of plagiarism, a focus on copying words and the presence of intentionality. Price (2009) made an extensive study of the perceptions of staff and students regarding one UK university's policies and penalties, and found some differences and problems for students, including insufficient attention drawn to the policies and possible misunderstandings. Therefore, this study builds on Price's by further exploring the perceptions of staff and students at another UK university about the plagiarism definition, and examining their experiences of plagiarism education. It focuses on the specific experiences of international postgraduate students, and for further insights, the study also aims to compare and contextualise their views with those of their tutors, and a number of globally known experts in plagiarism education.

\section{Methodology}

The study took place at Oxford Brookes University, UK, and was approved by the University Research Ethics Committee at this institution. The eight student participants in this study were from China, Japan, Sri Lanka and Algeria. Only international students were chosen for this study, as they currently make up the largest group of postgraduate students at the institution. I aimed to examine their views and experiences in order to establish how well they understood the university definition, and how effective their plagiarism education appeared to be. I also wanted to investigate the perception, wrongly, or rightly, that tutors associate problems of plagiarism with international students.

At the time of the study, they had completed a Pre-Master's programme of English for Academic Purposes (EAP) and were at the final dissertation stage of Master's degrees in business, technology or social science. Eight tutors who taught on the students' Master's programmes were also interviewed. Extracts from the student and tutor participant interviews will be analysed in relation to the following four areas: understandings of the university definition of plagiarism, tutor requirements of student source use, perceptions of plagiarism education, and perceptions of a link between international students and plagiarism. For anonymity of participants, students will be referred to as S1-8 and postgraduate tutors as T1-8.

As an adjunct to this data and in order to gain further insights into the current issues, four well-known experts in plagiarism education were interviewed via Skype. These experts were chosen based on their prominent and global-reaching research into plagiarism education. They agreed to their names being used in this study: Jude Carroll from Oxford Brookes University, UK, Diane Pecorari from Mälardalen University ${ }^{2}$, Sweden, Rebecca Moore Howard from Syracuse University, USA and Wendy Sutherland-Smith from Deakin University, Australia. 


\section{Findings}

\section{Understandings of the university definition of plagiarism}

The definition provided by the university in student programme guides is "Plagiarism taking or using another person's thoughts, writings or inventions as your own" (Oxford Brookes University, 2012). In their responses, students indicated some problems with this definition:

S1: It didn't mention ... what exactly is the plagiarism but it said it's using another's thoughts, actually we do it, in our study, we always [use] people's knowledge, so maybe [it] should write 'you should always reference the authors when you [use] their words'.

S2: This is not really a good definition because when you [write] something, you should take or use another's sorts of information or writings, but you have to mention who [has] written this and put the full reference.

S3: Maybe it should add something more... like 'without citation' and mention where is the source from.

S5: I don't think it's clear because if I make clear citation or reference, so it's not taking or using another person's ideas, the statement of this definition is not plagiarism.

S7: So every single report or you know, dissertation or essay, must be based on the other people's writing or thoughts so if someone says like this, 'taking or using another person's thoughts, we can't', this means we can't use other person's thoughts, but we have to use [them].

The students thought that the definition should say that plagiarism was taking sources 'without citation'. They did not comment about the expression 'as your own' and seem to have overlooked, or not to have understood this part of the definition. Several students interpreted this definition to mean that they could not use sources, which indicates that they did not understand the wording of the definition. It seemed to be presenting them with a dilemma, as they knew they had to use sources, but thought that this definition was telling them they could not use sources. In contrast, some tutors responded with positive views:

T1: It's quite simple and it gets through the issue that it's actually perceivable as your own view. I guess it helps to pick up those people who have just cut and pasted and put it in as their own work.

T3: I have never really thought about it. I quite like it, it is a nice simple one, that covers the range of things that people may think about as plagiarism.

\section{T4: That seems right to me.}

These views from tutors indicate that they found the definition 'simple' and 'right', while none of the student participants saw it in this way. However, some tutors did point out problems with the definition, such as aspects they felt were missing:

T1: I don't think it entirely captures everything, because I think when you think about what is happening there, I think there is a suggestion that something is morally wrong, often what lies behind everybody's tension about the whole idea of plagiarism is that there is an intention to do something This is a sanitised version of plagiarism, because plagiarism, as I would understand, a dictionary definition of it would be something where there was a conscious intent or conscious knowledge of what one was doing. 
T2: I think there needs to be a distinguishing between deliberate and nondeliberate, accidental plagiarism.

T5: There would need to be examples given to follow on from that.

T7: Do you know what, something that stands out for me, and it's never ever made me realise it, that it's got 'another person's', as if taking from a group's 'thoughts, writings and inventions' isn't so much of an issue.

Thus, tutors highlighted the need for the definition to take in the factors of group authors, the intention to plagiarise and some examples to explain it. However, none of the tutors suggested including 'without citation', as the students did. One word in the definition was commented on by the tutors, which was 'inventions':

T1: The use of the word 'inventions' is obviously difficult..., because we are not in an environment where we are using inventions.

T2: International students may question 'inventions'.

T5: [International students] might find 'inventions' a little bit, 'what does inventions mean?'.

T7: I think for students... working in sciences or technology, they would understand 'inventions', but would a business school student understand inventions?

Thus, some tutors were concerned about the word 'inventions' because they felt it did not fit the disciplinary environment for business and that international students would not understand it. In fact, some international students also commented that they were unclear about it.

\section{S3: What's the meaning about 'inventions'?}

S7: 'Inventions'? Not as clear as 'thoughts and writings'.

The use of the word 'inventions' in the definition thus provoked some concern for both students and tutors, but it seemed more important for the tutors, who tended to examine the definition word by word, while students looked at what was missing in the definition.

It is essential for students to understand university definitions of plagiarism. However, regardless of the definition used, as one of the expert interviewees, Wendy Sutherland-Smith, argues, plagiarism education is about more than following regulations:

One of the biggest challenges is the need to reclaim the area of plagiarism education in terms of teaching and learning, and take back that turf in the area of learning and teaching, so to move it out of punitive, punishing wrongdoers, that whole sort of find and catch, detect and punish, carrot and stick kind of thing and take it back to - so what are the students going to learn from this?

In this way, Wendy Sutherland-Smith highlights the need to move away from what students should not do, and look more at what they should do. The next section will focus on perceptions of what tutors required students to do with source use. 


\section{Tutor requirements of students' source use}

The student participants pointed out some of the approaches to source use that their tutors required them to take:

S2: The tutor of this module said he didn't like quotation... he said quotation is not really good, so. He said 'just if you really want to say something from this book, you just try to use your own words, so try not to use quotation', so I didn't use.

S4: My supervisor required me to do this, to use journal articles as my main source, so I use journal articles as my major source.

S8: I printed some of journals like that and then I showed them to my tutor, and asked if it was OK to use them, were they credible.

These responses indicate that students tried to follow their tutor's advice and requirements, including their individual preferences, such as 'he didn't like quotation... so I didn't use'. The students' comments reveal that they were concerned with selecting sources and use of quotations. In contrast, the tutor participants commented on complex skills in source use which they expected students to be able to demonstrate:

T1: We want them to critically evaluate the information they find. To debate issues, and as they progress through the programme, to increase that ability to debate, so that when they get to something like the dissertation, they are comfortable with the issue of debating, especially in the literature review, so within that debating, we will be comparing, contrasting different perspectives that writers will have in relation to a theory, a model, about how an organisation has been successful or perhaps why an organisation has failed. Not everyone may agree on those things. So linked also into that is the ability to synthesise information from that pool of resources that they've looked at. ...We say 'we want you to think independently, we want you to challenge the theories, the models, the concepts'.

T5: Our overall expectation at Master's level obviously is that students are using the sources effectively, not copying and pasting these sources in, but using them to develop and build arguments.

T3: We expect them to use the Harvard referencing system pretty much perfectly, so we pretty much expect that the moment they submit their first proper assessed bit of coursework that they can use the referencing system correctly, that means the whole shebang, so if they have made quotes, that they are in quotation marks with page numbers, that references at the end are properly formatted.

These comments indicate that the tutors had very high expectations of students' ability to use sources. They considered students should be able to critically evaluate what they read, build their own arguments, use the referencing system perfectly, be comfortable with debate, and synthesise information. On the demands for international students to use sources at this level, Rebecca Moore Howard gave the following view:

First of all, what we are asking international students to do is ridiculous, it's not possible. Unless there is some way to sort of inject vocabulary into international students, you know, it is not a question of them just knowing the rules, but it is a question of them acquiring the facility with English to allow them to do anything but cut and paste and patchwrite. 
Thus, Rebecca Moore Howard's very strong argument makes clear that the requirement to use sources in sophisticated ways can be unrealistic for some international students, if they have a smaller vocabulary range or are unable to construct complex sentences to adequately express their ideas.

The next section goes on to examine the availability of plagiarism education.

\section{Perceptions of plagiarism education}

With regard to the teaching context of plagiarism education, tutors were asked how they taught students about source use and avoiding plagiarism.

T3: We do work during the induction, we do work with the Academic Conduct Officer in the first week of the course, and on one of the modules we do a formative assessment where they get to practise and we correct that.

T5: That's partly done in our induction and partly done in our early Personal Development Planning module as well, and Harvard reference guide.

T6: They get a little bit on induction, but then we have the research methods module whose sole purpose is to support them through the dissertation process, through the research process. They also take Personal Development and Leadership, in semester 1 . That's really focusing on academic literacies and academic inquiry skills.

In these comments, tutors highlight the induction week as key input for plagiarism education, and mention other instruction: in the personal development and research methods modules, and through formative assessment. Therefore, the tutors' view seems to be that a considerable amount of input is provided. However, the students' perceptions of the plagiarism education available were very different.

S5: When you start your Master's degree, nobody [tells] you anything about plagiarism. Well we've got one session about this, but it's in the main theatre, and nobody really cares about this, so some people are sleeping. I mean, they're gonna tell you about plagiarism and referencing once or twice but that's it, they're gonna move on.

S6: In the first semester they gave us like a guideline about the issues about paraphrasing, especially about the issues about how to cite and how to write your bibliography, especially this one, they emphasise a lot on this one, just how it needs to be. We had a kind of workshop on that, maybe once, twice. The second semester, we are expected to do these things more properly, to use the guidelines much more properly, they are not going to tell you how again, basically I mean, you are supposed to know.

These comments show that students felt they received very little instruction or advice about plagiarism on their Master's programmes, and after the initial induction and one or two workshops, they felt they were 'supposed to know'. Some tutors gave other views about the support available:

T4: They do that in semester 1 and in that they are taught all of those sorts of things, you know, they are taught how to cite, how to quote and so on, and actually how to find literature and sources. So I simply say, 'Right, that is what you have been taught, this is what you must do'.

Thus, T4 considers that plagiarism education takes place before they teach the student, at an early stage of the Master's course, and therefore, by their reasoning, is 
not the tutor's responsibility. On the other hand, $\mathrm{T7}$ believed plagiarism education to be important, but gave another reason not to teach it:

T7: This won't be a surprise to any academic, but we just don't have that time to sit and have that time with students, and when you do, it's so great for you because you see that kind of excitement and understanding, and things all slotting into place, their studies start to make sense and that is so important. To me, formative feedback is the most important thing, but it's also the hardest thing to do, because you just don't have the time to do it, it isn't scheduled.

T7 acknowledges the importance of plagiarism education but feels there is no time to provide it. However, some tutors clearly did not want to provide support:

T1: Some students will try, and get completely lost in trying to paraphrase, because they then run into grammatical structure issues and then you'll, as a marker, you are trying to read through this, and I just don't understand what this paragraph indicates and recently, l've said 'I think you need to go to Oxford Brookes International'.

T2: It is not part of the normal module leader's role to say 'We are now going to tell you about sourcing and referencing', you know, because we've got stuff to teach. How much there is on sourcing and so on, I wouldn't like to say, nor when it appears in the syllabus.

These comments seem to show that tutors felt it was not their responsibility to provide plagiarism education, and that the problem could be sent to another, more appropriate department, such as EAP. Jude Carroll commented on the tendency for tutors to direct students elsewhere:

I think that it's very easy to ghettoise plagiarism as an issue, so it's very easy to send it to student support, it's very easy to send it to English language support people, it's very easy to send it to first year any sort of study skills type of people. It's very easy to ghettoise it and there's a very strong temptation amongst academics, who are just bombarded, to say 'Could I just send this student away to be fixed, and when this student is (what I used to call) 'oven ready', send them back to me and then I'll teach them'. That attitude has not gone away, it really hasn't. The 'oven ready' student is every academic's dream.

Jude Carroll's perception that tutors prefer an 'oven ready' student who has been given plagiarism education elsewhere reflects the problems of time pressure and heavy workloads for many tutors, as voiced by T7 above.

Students reported worries and concerns about plagiarism, especially with their final Master's dissertations. Some of these concerns show gaps in their knowledge of how to use sources and a lack of confidence in their strategies.

S1: When I [write], I try to change every word I use, make sure it's different from the other authors' work and maybe sometimes I will ask my tutor to check it with their system, if it is possible.

In this extract, S1 explains the extent of their laborious safety strategy to avoid plagiarism by changing every word of source text, and even recounts that they also asked their tutor to make a check, presumably through Turnitin, before submission. S3 also looked for tutor support: 
S3: I try to make all my sources which I arrange more [logically] but sometimes I still confused about where I can say my idea and where I should just use other people's words. I try to contact with my supervisor and want to have some support from him.

S3's main concern here is about where to use their own words and ideas, and where to use those from sources. It seems unexpected that at the dissertation writing stage, the student still had quite basic questions about using sources. Similarly, S7 had doubts about source use:

S7: About Master's dissertation - I'm quite worry about it because most of the source is from the internet and I'm not sure if it's the right opinion, if it's the academic opinion or not.

S7 was concerned about whether using internet sources was acceptable. This student seemed to have a limited understanding of how to engage with sources, as they were looking for 'the right opinion'. Thus, they did not appear able to undertake the critical evaluation required by their tutor (see comment by T1 in the 'Tutor requirements' section). S2 voiced even stronger concerns:

S2: I've got a question, is it really so strict, in the uni, this problem about plagiarism? I mean not the very obvious plagiarism, just copy or just take another dissertation, another work as your own. I mean like if you just copied something, a paragraph, then you didn't give the citation or something, if you did that, then you will fail, is the question I've got. So I'm worried about that, that's why l'm asking myself, different tutors, they have different opinions, so maybe this tutor, he will say 'That's fine' if you do it, and another tutor say, 'You can't do that'. The first year, I mean, I was studying here, I was very cautious about this problem, but now this year, nobody mention about this problem in all my assignments. So that's why, I ask myself that question, if they don't mind, or they just didn't mention, or they didn't find l've got some problem, I don't know. I want some feedback so that would make me know I shouldn't do that, or I can't do it, but now, l'm lost, like.

This very powerful account from S2 reflects quite an extreme level of anxiety and hopelessness, ending in 'I'm lost'. S2's comment that 'different tutors, they have different opinions' reflects this student's view that there is inconsistency between tutors about plagiarism. The reasons for this cannot easily be assumed, but it is possible that their tutors came from different backgrounds or education systems, or understood plagiarism differently. The comment also highlights the need for greater availability of support from tutors about avoiding plagiarism. Surprisingly then, the tutor participants indicated that they readily supported students who had problems:

T5: We say 'If you've got any doubts about what you are doing and how you do it, please come and talk to us as the research methods module leaders', and people do.

T6: You have to be really ready to support them. And they won't come to you for support either, so you have to be on the ball and aware and trying to diagnose problems.

These indications of support available from tutors do not seem to match the student perceptions of support, nor the studies that suggest that tutors have no time in their workload to offer this support. 
4. Perceptions of a connection between international students and plagiarism Some tutor participants commented on their perceptions of a connection between international students and plagiarism:

T2: All the most serious examples of plagiarism that I personally have come across have been from international students.

T4: With an overseas student, well not all of them, but almost all of them, you would spot plagiarism in their initial work a mile off, because it is grammatically correct and this is kamikaze on their part quite honestly.

T5: It would be more with our international students, cases of plagiarism which are referred.

The tutors' comments indicate that they were certain of a relationship between international students and plagiarism, as they thought there were both a greater number of cases and more serious cases among international students. They also thought these cases were easy to spot. In addition, they gave some reasons for finding more plagiarism among international students:

T1: They have not been through the UK higher education system and there are mixed abilities in terms of independent research and inquiry. Typically students from South East Asia, Africa, they are used to the tutor being able to provide the answers.

T5: More due to the ignorance rather than the deliberate cheating.

T6: It is the background of whatever institution they have come from. 'Copying, well, no one ever told me about that, referencing, what are you talking about?' And I think that's probably quite a strong reason.

In these comments, it can be seen that these tutors assumed international students plagiarised because they came from a different educational culture and had not learnt about plagiarism in their current one. This different educational culture could include a different $\mathrm{L} 1$, and different regulations about source use. However, it is useful here to consider Diane Pecorari's report of her study of the responses of tutors in Sweden, where she works, to international students and plagiarism:

If their Swedish students would have been in the US, they are the international students, here it is the international students, not the Swedish students who are perceived to be the problem, and that makes me suspect that there is something 'them and us' about this. You know, it can't be the fact that only the international students, ie non-native English speakers, have a greater proclivity to plagiarise, the Swedish students would be in the same boat as the German exchange students coming to Sweden.

Diane Pecorari's sense that there is a 'them and us' relationship between the international students and the academic environment they are in, seems very significant. It suggests that the mere fact that students are originally from a different educational environment to their current one seems to mark them out as potential plagiarists, and influences the perception of tutors towards them.

\section{Discussion}

\section{Different perceptions of plagiarism definition}

The perspectives of students and tutors regarding the university plagiarism definition were clearly different. This is consistent with an investigation by Price (2009) which 
found that there is very little agreement, even within the same institutions, about what constitutes plagiarism. The students' views expressed here provide some evidence to suggest that plagiarism definitions can be unclear to students, perhaps especially to international students. This finding also endorses the view of Carroll (2007) that students and tutors often understand plagiarism definitions differently or do not even understand them. It is very difficult for all stakeholders to agree on definitions of plagiarism (Sutherland-Smith, 2008), but institutions should take care to provide one to students and tutors that can be clearly understood, perhaps even in each student's L1.

In order to avoid the problem of students misunderstanding or not understanding plagiarism definitions, it would seem useful to consult students when writing the definition, and to spend time discussing the definition that students are expected to follow within a plagiarism education class. Furthermore, as pointed out by Pecorari (2001) and Price (2009), the location of and access to definitions of plagiarism need to be made clear to students. If students' attention is not drawn to the definitions, institutions may be doing students a disservice, as Pecorari (2001, p. 237) argues: "it is perhaps fair to wonder whether definitions found in documents students are unlikely to read closely are intended primarily to inform students or to serve as the basis for taking actions against those who have violated the rules".

It seems that tutors prioritised different issues within plagiarism, since they responded differently to the definition. Therefore, as recommended by Carroll (2007), this study also calls for more discussion and consultation among tutors about how plagiarism should be defined. As plagiarism also grows over time (for example, now it includes engaging the services of the plentiful essay writing websites) and the means of detecting it develop, these discussions and consultations should be ongoing.

\section{Tutors' high requirements of student source use}

The tutors in this study acknowledged that they had high requirements of student source use. They expected students to use referencing systems 'perfectly', to 'critically evaluate' and be 'comfortable with debate'. These requirements for postgraduate students to demonstrate high levels of source use support the findings by Petrić (2007). She showed that there is a relationship between students' ability to use citation and the grade they receive; in order to get higher grades, students needed to do more than simply attribute ideas, but also use more sophisticated functions of citation such as synthesis, evaluation and exemplification. It needs to be debated whether this high level of source use is achievable and realistic, for international students in particular. In this research, one expert, Rebecca Moore Howard, has argued that these requirements are 'ridiculous' and 'not possible'. A similar conclusion was also reached by Pittam et al. (2009) who illustrated the difficulties, especially for international students, of establishing an authorial identity when they did not feel they had their own words or could not express their opinion in an acceptable way. For example, in Pittam et al.'s study, one Asian participant complained that they had a different opinion to published Western research, but had no means to back it up because Asian sources were unavailable. Therefore, tutors need to be more aware of the difficulties for some international students to follow their requirements for source use.

One of the requirements made by tutors in the study was to 'challenge' theories. This may be seen as a particular difficulty for international students whose educational background has not encouraged this approach to published work. This point also supports the analysis by Spack (1997) of a Japanese student participant who struggles with the need to approach sources in this way, until coming to the realisation that it is essential for her to construct knowledge from her interpretation of source use. The students in this research had doubts about their ability; showing the capacity to challenge theories and maintain a clear authorial voice can only be achieved over time and through extensive language development and plagiarism education. 


\section{Different perceptions of plagiarism education}

This study also found a gulf between tutors and students in relation to their perceptions of the availability of plagiarism education, with some tutors saying there are programmes focusing on academic literacies and 'all of those sorts of things', while some students said 'nobody [tells] you' and 'you are supposed to know'. This finding was also highlighted in recent research by the Royal Literary Fund, which called for more instruction in academic writing in UK universities (Murray \& Kirton, 2006). Their research was critiqued by O'Neill (2008), who suggested one method of improving academic writing would be a mentoring scheme with students taking on the role of peer tutors. This might also be a means of making plagiarism education more available.

The study also shows that students continued to have concerns about plagiarism and did not feel sufficiently supported to deal with these concerns. Some tutors felt they gave enough support, while others said they did not have enough time or thought it was not their role. These findings are consistent with those in a study by Hall and Sung (2009) which indicated the lack of support for international postgraduate students in terms of academic literacy. They argue that if international students are admitted to these programmes, adequate support for them to avoid plagiarism should be in place. Carroll (2007) also calls for much greater support through developing resources, offering more practice, and giving more attention to procedures and staff development.

One of the issues raised by students was concerns about using internet sources for academic arguments. There may be a wide gap between the expectations and perceptions of tutors and students in how they gain information, as found in a study by Blum (2009). As she suggests, tutors may see citation rules very clearly after years of practice, but current students, who are engaging in multiple text use, may not see these rules as clearly. Blum says "contemporary students are swimming in a sea of texts" (2009, p. 4) and this may blur their concept of attributing words and ideas clearly to authors. Thus, tutors may need to become more aware of the actual practices of their students when using sources.

\section{Connection between international students and plagiarism}

The perception among academics that international students are closely linked to plagiarism has been established in many studies (for example, Bennett, 2005). The accuracy of this perception is open to debate. However, it is important to recognise the needs of international students, so that they can avoid this automatic link to plagiarism. Schmitt (2005) has indicated that there is a strong relationship between the language level of international students and their ability to write assignments appropriately. This has been further demonstrated by Introna and Hayes (2004), who have argued that the labelling of international students as plagiarists is unfair, since often these students are trying to use the appropriate academic discourse in the expert words of a text and tend to 'patchwrite' through lack of vocabulary and understanding. As a consequence, what they write can be more easily matched to source text. As text-matching tools focus on plagiarism at the word string level, international students' copying of words is more visible than, for example, native speakers' use of ideas (Introna \& Hayes, 2004).

Diane Pecorari's claim that there is a 'them and us' element to the connection between international students and plagiarism gives a useful insight into the reason for this perception. If it is the case that tutors make a connection between international students and plagiarism, wherever and whoever they are, it does seem to suggest tutors see international students as plagiarists, simply because they are outsiders to their current educational context. What may be bound up in tutors' views of different 
educational contexts is the argument that there are different cultural approaches to plagiarism (Bennett, 2005; Hall \& Sung, 2009; Introna \& Hayes, 2004) and that nonnative speakers struggle to understand plagiarism in English-medium universities (Braine, 2002; Spack, 1997). However, the 'outsider' argument would also mean that English-speaking students would have difficulty with plagiarism in other contexts, a currently unresearched area.

\section{Conclusion}

This study has highlighted some of the current issues in plagiarism education through the perceptions of international students, postgraduate tutors, and plagiarism education experts. Firstly, it has shown that a university definition of plagiarism is neither clear to students nor interpreted in the same way by tutors. It has therefore suggested that both tutors and students should be consulted in the creation of plagiarism definitions, and that they should continue discussing any changes in meaning. Secondly, it has found tutor requirements of students' source use to be very high, while also finding the levels of pedagogical support with source use to be rather low. Related to this, it has also noted the concerns of students regarding plagiarism and using sources appropriately. Thus, it calls for the requirements of students' source use to be matched by adequate levels of support, which would also reduce the concerns of students. Finally, it has shown that there is a tendency for tutors to perceive a connection between international students and plagiarism. This tendency should be examined, as it has important implications for international students, especially in terms of fairness. Overall, the study calls for more attention to plagiarism education, which should be a central part of the whole learning process, rather than a list of rules.

As a case study, this investigation is limited by the small number of participants within one university, and is therefore small-scale. It is also acknowledged that the research would benefit from the inclusion of home and native speaker students to examine and compare their views and experiences. However, the comparison between student and tutor views gives some weight to the study, and the views of globally known experts broaden the debate. Further research into experiences of plagiarism education at other universities using a greater number of participants, of more diverse disciplines and nationalities, including home and native speaker students, could build on this study.

\section{Footnotes}

1. 'International' students in this study refers to students who come from outside the UK, and are also non-native speakers of English.

2. At the time of the study. Diane Pecorari is now at Linnaeus University, Sweden.

\section{References}

Bennett, R. (2005). Factors associated with student plagiarism in a post-1992 university. Assessment and Evaluation in Higher Education, 30(2), 137-162.

Blum, S. (2009). My word! Plagiarism and college culture. New York: Cornell University Press.

Braine, G. (2002). Academic literacy and the non-native speaker graduate student. Journal of English for Academic Purposes, 1, 59-68.

Bull, J., Coughlin, E., Collins, C., \& Sharp, D. (2001). Technical review of plagiarism detection software report. Joint Information Systems Committee, 1-36. Retrieved October 22, 2012, from http://www.jisc.ac.uk/uploaded documents/ luton.pdf

Carroll, J. (2007). A handbook for deterring plagiarism in higher education (2nd ed.). Oxford: Oxford Centre for Staff and Learning Development. 
Chanock, K. (2008). When students reference plagiarised materials - what can we learn (and what can we do) about their understanding of attribution? International Journal for Educational Integrity, 4(1), 3-16.

Davis, M., \& Carroll, J. (2009). Formative feedback within plagiarism education: Is there a role for text-matching software? International Journal for Educational Integrity, 5(2), 58-70.

Hall, G., \& Sung, T. W.-C. (2009). Mind the gap? A case-study of the differing perceptions of international students and their lecturers on postgraduate business programmes. International Journal of Management Education, 8(1) 53 $-62$.

Howard, R. M. (2008). Plagiarizing (from) graduate students. In R.M. Howard \& A.E. Robillard (Eds.), Pluralizing plagiarism: Identities, contexts, pedagogies (pp. 92 -100). Portsmouth, NH: Boynton/Cook.

Introna, L., \& Hayes, N. (2004). Plagiarism, detection and intentionality: On the construction of plagiarists. In A. Smith \& F. Duggan (Eds.), Plagiarism: Prevention, practice and policy conference proceedings (pp. 83-95). Plagiarism Advisory Service, Newcastle, 28 -30 June.

McCulloch, S. (2012). Citations in search of a purpose: Source use and authorial voice in L2 student writing. International Journal for Educational Integrity, 8(1), 55-69.

McGowan, U. (2005). Does educational integrity mean teaching students NOT to 'use their own words'? International Journal for Educational Integrity, 1(1).

Murray, N., \& Kirton, B. (2006). Chapter 2: An analysis of the current situation. In S. Davies, D. Swinburne \& G. Williams (Eds.), Writing matters (pp. 7-14). London: Royal Literary Fund.

O’Neill, P. (2008). Using peer writing fellows in British universities: Complexities and possibilities. Across the Disciplines, 5, 1.

Oxford Brookes University (2012). Plagiarism definition (undergraduate modular programme guide). Retrieved October 23, 2012, from http://www.brookes.ac.uk/services/asd/registry/sas/student guide/c10.html

Pecorari, D. (2001). Plagiarism and international students: How the English-speaking university responds. In D. Belcher \& A. Hirvela (Eds.), Linking literacies: Perspectives on L2 reading-writing connections (pp. 229-245). Ann Arbor: University of Michigan Press.

Pecorari, D. (2008). Academic writing and plagiarism: A linguistic analysis. London: Continuum.

Petrić, B. (2007). Rhetorical functions of citations in high- and low-rated master's theses. Journal of English for Academic Purposes, 6, 238-253.

Pittam, G., Elander, J., Lusher, J., Fox, P., \& Payne, N. (2009). Student beliefs and attitudes about authorial identity in academic writing. Studies in Higher Education, 34(2) 153-170.

Price, J. (2009). Plagiarism in higher education: Consensus and consistency when punishing student cases. Unpublished PhD thesis, University of Southampton.

Schmitt, D. (2005). Writing in the international classroom. In J. Carroll \& J. Ryan. (Eds.), Teaching international students: Improving learning for all (pp. 63-74). Abingdon: Routledge.

Spack, R. (1997). The acquisition of academic literacy in a second language: A longitudinal case study. Written Communication, 14, 3-62.

Sutherland-Smith, W. (2008). Plagiarism, the internet and student learning: Improving academic integrity. New York: Routledge.

\section{About the author}

Mary Davis is a Senior Lecturer of English for Academic Purposes at Oxford Brookes International, Oxford Brookes University, UK, where she leads a Pre-Master's programme in English language and study skills. She is undertaking PhD research in the development of source use at the Institute of Education, University of London. Her research interests also include the formative use of Turnitin and the role of reusable phrases in academic writing. 